\title{
DINAMIKA INTERAKSI LEGISLATIF DAN EKSEKUTIF DI PULAU MOROTAI (Mengurai Konfigurasi Politik dan Penjelasan Alternatif)
}

\author{
Alwadud Lule* \\ alwadud_lule@yahoo.co.id \\ Indra Lesang, S.I.Kom., M.IP* \\ indralesang03@gmail.com
}

Dosen Universitas Pasifik (UNIPAS) Morotai

\begin{abstract}
Abstrak
Studi ini menguraikan fenomena interaksi antara lembaga legislatif dan eksekutif di Pulau Morotai pasca perhelatan demokrasi elektoral tahun 2017. Dalam catatan konfigurasi, interaksi antara kedua lembaga tersebut terlihat tidak demokratis melainkan berada pada relasi yang bersifat konfliktual meskipun pada akhirnya interaksi kuasa dalam arena tertentu berakhir dengan konsensus. Relasi kuasa yang konfliktual menstimuluskan penyelenggaraan pemerintahan daerah dengan memakai jalan yang tidak demokratis, sehingga dapat mengancam stabilitas demokrasi lokal. Resiko lain dari instabilitas demokrasi lokal adalah memungkinkan adanya ekspansi kekuatan Pemerintah Daerah secara kelembagaan ke tubuh DPRD untuk membentuk faksi politik mayoritas dengan orientasi mengamankan berbagai opsi kepentingan, baik yang berkorelasi dengan masalah kinerja pemerintahan daerah maupun ekonomi-politik di daerah. Dari rangkaian konfliktual dalam kerja relasional DPRD dan Bupati selalu saja berakhir dengan politik consensus. Pasca politik consensus hingga saat ini relasi kedua lembaga tersebut terlihat lebih stabil dan oposisi secara politik lenyap dari arena persaingan di legislatif.
\end{abstract}

Kata Kunci: Dinamika Interaksi, Konfigurasi Politik, Legislatif Daerah, dan Eksekutif Daerah.

\begin{abstract}
This study outlines the phenomenon of interaction between the legislative and executive institutions on Morotai Island after the electoral democracy event in 2017. In the configuration note, the interaction between the two institutions does not appear to be democratic but is in a conflictual relationship, although in the end the interaction of power in certain arenas ends with consensus. Conflictual power relations stimulate the administration of regional government by using undemocratic paths, which can threaten the stability of local democracy. Another risk of the instability of local democracy is the possibility of institutional expansion of the Regional Government's power into the body of the DPRD to form a majority political faction with an orientation to secure various interest options, both correlated with issues of regional government performance and the political
\end{abstract}


economy in the region. From a series of conflicts in the relational work of the DPRD and the Bupati always ends with a political consensus. After the political consensus up to now the relations between the two institutions seem to be more stable and political opposition disappears from the arena of competition in the legislature.

Keywords: Dynamics of Interaction, Political Configuration, Regional Legislature, and Regional Executive.

\section{PENDAHULUAN}

Dinamika penyelenggaraan pemerintahan daerah pasca reformasi dengan gaung UU No 23 Tahun 2014 tentang Pemerintahan Daerah merupakan bagian dari dimensi perkembangan kebijakan hukum otonomi daerah di Indonesia. Perubahan signifikan dan menarik untuk dikaji dalam dinamika tersebut adalah mengenai diskursus seputar penerapan sistem pemilihan kepala daerah dan wakil kepala daerah secara langsung dan relasi kewenangan antara legislatif dan eksekutif daerah. Tentunya, penerapan sistem ini tidak dengan alasan melainkan mengupayakan agar kedaulatan rakyat secara substansi terinstitusionlitas dalam setiap kewenangan kelembagaan. Selain itu, penerapan sistem pemilihan kepala daerah secara langsung merupakan sebuah konsekuensi logis dari amanah UUD 1945 pasca amandemen.

Signifikansi penerapan sistem pemilihan langsung juga berkonsekuensi terhadap legitimasi politik kepala daerah dalam melaksanakan aktifitas publik. Dimana kepala daerah merasa punya keabsahan yang kuat karena kedudukannya ditentukan langusng oleh kehendak rakyat mayoritas. Tidak hanya kepala daerah, DPRD secara konstitusional juga mempunyai legitimasi kuat dalam menjalankan tugas dan kewenangannya karena kedudukan/kekuasaannya bersumber dari kedaulatan rakyat. Dengan demikian, kedua penyelenggara pemerintahan daerah (pemerintah daerah dan DPRD) merupakan manifestasi kedaulatan rakyat di daerah.

Dari rasionalitas tersebut diatas, kemudian dipandang perlu merumuskan mekanisme hubungan kewenangan antara legislatif (DPRD) dan eksekutif (pemerintah daerah) untuk menciptakan stabilitas demokrasi lokal dan efektifitas 
birokrasi. Desain kelembagaan antara legislatif dan eksekutif di daerah dikonstruksikan secara yuridis sebagai mitra kerja dalam lingkup penyelenggaraan pemerintahan daerah. Mekanisme kelembagaan seperti itu lah yang memberikan konstribusi terhadap stabilitas demokrasi lokal, karena setiap isu yang berkembang ditengah penerapan sistem pemerintahan daerah dapat diminimalisir melalui mekanisme persetujuan bersama dan mengutamakan aspek kerja sama.

Perkembangan literatur seputar relasi legislatif-eksekutif di daerah dalam bingkai hubungan kewenangan dapat diidentifikasi dan dipetakan dalam dua pola. Pola pertama memberikan artikulasi bahwa relasi legislatif-eksekutif daerah secara politik hukum menampilakan aspek determinasi oleh salah satu lembaga. Hal tersebut pernah tercatat dalam lembaran sejarah Orde Baru, dimana Pemerintah Daerah selalu determinan terhadap DRPD dalam setiap aktifitas pemerintahan daerah. Karena kepala daerah domainnya tidak hanya menjalankan fungsi sebagai kepala daerah melainkan melaksanakan sebagian tugas pemerintahan dengan kapasitasnya sebagai Wakil Pemerintah Pusat di daerah. Sehingga hal ini telah membuahkan justifikasi bahwa relasi legislatif-eksekutif daerah di jaman Orde Baru bersifat dominatif.

Pola kedua, secara politik hukum menguatkan kedua lembaga dengan tugas dan kewenangan masing-masing yang didasarkan pada relasi yang bersifat demokratis. Pola demokratis ini dipengaruhi oleh konfigurasi politik dan hukum di era reformasi yang menghendaki adanya penerapan sistem check and balance dalam hubungan kewenangan antara legislatif dan eksekutif daerah. Perubahan paradigma tersebut kemudian melahirkan interaksi kewenangan antara Pemerintah Daerah dan DPRD dalam penyelenggaraan pemerintahan yang meliputi tiga aspek, yakni (i) pembentukan Peraturan Daerah, (ii) penentuan Anggaran Pendapatan dan Belanja Daerah (APBD), dan (iii) pelaksanaan fungsi pengawasan DPRD.

Sebagaimana juga dialami oleh daerah-daerah yang baru selesai melaksanakan demokrasi elektoral (Pilkada), interaksi antara lembaga legislatif dan eksekutif Pulau Morotai pasca perhelatan pesta elektoral tahun 2017 dipandang relatif dinamis dengan ragam variabel politik. Fakta menunjukan 
bahwa keperpihakan sebagian anggota DPRD terhadap Pemerintah Daerah (Bupati) dalam berbagai isu merupakan bentuk dukungan terhadap argumentasi politik dan kebijakan-kebijakan Pemerintah Daerah.

Tercatat ada sekian isu dalam wacana interaksi legislatif dan eksekutif Pulau Morotai telah menambah dinamika interaksi kedua lembaga tersebut. Terutama berkaitan dengan relasi pembentukan peraturan daerah dan penentuan APBD. Karena jauh sebelumnya interaksi legislatif dan eksekutif Pulau Morotai berada pada posisi kontradiksi dan tidak demokratis, maka penentuan alokasi APBD selalu menuai perdebatan dan konflik kepentingan. Meski demikian, pasca Pilkada 2017 hingga saat ini, praktik pembahasan anggaran tidak ada silang pendapat yang berakhir deadlock anggaran. Namun kekuasaan merumuskan anggaran tersebut menjadi sumber polemik yang menambah intensitas dinamika kerja relasional antara DPRD dan Bupati karena praktik-praktik informal seperti perdebatan kepentingan dan upaya mendeligitamasikan anggaran.

Perdebatan yang muncul dalam rapat pembahasan merupakan dinamika yang lazim terjadi hampir disetiap tahun anggaran. Karena mekanisme interaksi antar DPRD dan Bupati dalam kondisi tertentu saling mendominasi ketimbang bersifat check and balance. Tindakan mendominasi antara kedua kekuasaan ini masing-masing diorientasikan untuk memobilisir kepentingan dan program agar dapat terakomodir saat proses penentuan dan alokasi anggaran.

Meski demikian, interaksi antara DPRD dan Bupati di Pulau Morotai khusunya pada proses pembahasan rancangan Perda relatif jauh lebih dinamis, daripada pembahasan rancangan Perda APBD yang menyumbangkan begitu tinggi kedinamisan interaksi. Namun, tidak bisa dipungkiri ada beberapa hal memang terjadi konflik tetapi sejauh ini kita tidak menemukan adanya kebuntuan kerja relasional. Selama periode 2017-2019, rancangan Perda yang dibahas oleh kedua lembaga tersebut tidak pernah menemui kebuntuan. Rancangan Perda Pembiayaan Kontrak Tahun Jamak Kabupaten Pulau Morotai 2019-2021 merupakan satu diantara rancangan Perda yang sempat mengalami perdebatan panas walaupun pada akhirnya berhasil diundangkan. 
Kerja relasional antara DPRD dan Bupati Pulau Morotai selalu mengkonfirmasi perdebatan walaupun pada akhirnya bermuara pada konsensus. Hal tersebut menunjukan bahwa desain kelembagaan eksekutif dan legislatif daerah memiliki mekanisme yang interdependensi. Sehingga kebuntuan dalam proses kerja relasional antara kedua lembaga tersebut, baik dalam perumusan anggaran maupun proses legislasi dapat terhindarkan. Meski demikian, tidak bisa dipungkiri beberapa konflik telah menambah dinamika interaksi antara DPRD dan Bupati. Dinamika tersebut juga telah membentuk pola interaksi konfliktual dan tidak demokratis.

Sekarang kita bisa mendiskripsikan pola interaksi DPRD dan Bupati dalam mekanisme kerja relasional dengan mengembangkan argument bahwa, interaksi kedua kekuasaan ini berjalan dibarengi dengan perdebatan kepentingan dan akhirnya terlihat tidak demokratis melainkan berada pada relasi yang bersifat konfliktual. Selain itu, manuver politik adalah kunci utama dalam menyelesaikan debat kepentingan. Karena interaksi antar DPRD dan Bupati dalam lingkup maneuver politik memperlihatkan dinamika yang menarik. Dinamika ini tentunya bersumber dari inkonsistensi sikap "anggota DPRD” yang dalam lembaga memiliki posisi kunci dan berpengaruh. Kita temukan ada upaya pemerintah daerah mencari jalan alternative untuk menstabilkan interaksi dengan DPRD melalui sikap kompromistis.

Jika interaksi legislatif dan eksukutif daerah berada pada pola yang tidak demokratis seperti uraian diatas, maka pada aras program dan penentuan politik anggaran akan memicu potensi saling sandra antara pemerintah daerah dengan DPRD. Geliat demikian menstimuluskan penyelenggaraan pemerintahan daerah dengan memakai jalan yang tidak demokratis, sehingga dapat mengancam stabilitas demokrasi lokal. Resiko lain dari instabilitas demokrasi lokal adalah memungkinkan adanya ekspansi kekuatan Pemerintah Daerah secara kelembagaan ke tubuh DPRD untuk membentuk faksi politik mayoritas dengan orientasi mengamankan berbagai opsi kepentingan, baik yang berkorelasi dengan masalah kinerja pemerintahan daerah maupun ekonomi-politik di daerah. 


\section{METODE PENELITIAN}

Jenis penelitian yang diguanakan adalah deskrptif kualitatif. Tipe penelitian ini akan memberikan deskripsi tentang hubungan atau interaksi legislatif (DPRD) dan eksekutif (pemerintah daerah) di Pulau Morotai. Selain itu, penelitian ini berusaha mengungkap konfigurasi politik yang berkembangan dalam ruang lingkup relasi eksekutif-legislatif di Pulau Morotai pasca perhelatan demokrasi elektoral tahun 2017.

\section{HASIL DAN PEMBAHASAN}

\section{Dinamika Interaksi DPRD dan Bupati}

Interaksi lembaga legislatif dan eksekutif merupakan komponen kunci dalam memberikan jaminan penyelenggaraan pemerintahan yang efektif dan stabil. Konklusi demikian berdasar pada konsepsi bahwa efektifitas dan stabilitas politik dan demokrasi ditentukan oleh institusi-institusi politik yang berada dalam struktur ketatanegaraan, baik secara mandiri oleh institusi maupun dalam lingkup relasi antar sesama institusi. Diantara interaksi kuasa dalam struktur politik yang dianggap penting untuk mendapatkan perhatian, terutama dalam rezim demokrasi adalah relasi antara eksekutif dan legislatif daerah (Bupati dan DPRD).

Sebagian kalangan memfokuskan pembahasan mengenai relasi eksekutif (Presiden) dan legislatif (DPR) dalam bingkai presidensialisme multi partai. Namun pembahasan interaksi eksekutif dan legislatif di daerah dengan pendekatan multi partai sama sekali tidak masuk dalam daftar isu krusial. Mungkin karena variable pengaruhnya terletak pada pilihan keputusan yang diambil oleh anggota partai politik dalam parlemen tidak ditentutakan oleh instrument ideologi partai melainkan lebih pada isu politis yang diperankan oleh personal anggota DPRD. Sehingga kekuatan partai politik dalam arena parlemen lokal tidak menjadi variable determinan.

Interaksi DPRD dan Bupati Pulau Morotai dikonstruksikan melalui relasi kewenangan antar kedua lembaga tersebut. Mekanisme yang mengatur kerja relasional antara DPRD dan Bupati dibagi ke dalam beberapa fungsi utama 
DPRD, yaitu pembahasan mengenai anggaran, pembentukan peraturan daerah, dan pengawasan.

\section{Dinamika Interaksi dalam Dimensi Politik Anggaran}

Argumentasi mengenai politik anggaran didasarkan atas beberapa isu yang telah memberikan kontribusi terhadap dinamika kerja relasional antara DPRD dan Bupati Pulau Morotai. Pertama, siapa yang memiliki kewenangan lebih dalam merumuskan anggaran, apakah DPRD ataukah Bupati? Kedua, apakah dalam proses pembahasan anggaran relasi kedua lembaga tersebut bersifat konfliktual, atau sebaliknya, setiap keputusan politik anggaran bermuara pada tindakan kompromistis.

Undang-undang pemerintahan daerah mengatur mekanisme interaksi antar DPRD dan Bupati dalam proses pembahasan anggaran dengan menempatkan kedua lembaga tersebut sebagai mitra kerja yang sejajar. Meskipun dilain sisi, eksekutif daerah diberikan keistimewaan karena memiliki kekuasaan insiatif dan kecakapan mumpuni dalam mendesain anggaran. Sedangkan DPRD, dalam membangun mitra kerja, memiliki wewenang untuk mengubah anggaran melalui persetujuan bersama. Mekanisme demikian merupakan pola yang saling mengunci antara DPRD dan Bupati, sehingga dalam proses pembahasan anggaran, walaupun praktik informal dan perkembangan dinamika terus berlanjut, akan tetapi proses penentuan dan alokasi anggaran setiap tahun antara DPRD dan Bupati relatif berjalan baik.

Selama berjalannya pemerintahan Benny Laos, praktik pembahasan anggaran dari 2017 hingga saat ini, tidak ada silang pendapat yang berakhir deadlock anggaran. Namun kekuasaan merumuskan anggaran tersebut menjadi sumber polemik yang menambah intensitas dinamika kerja relasional antara DPRD dan Bupati karena praktik-praktik informal seperti perdebatan kepentingan selalu mewarnai proses pembahasan hingga mendeligitimasi anggaran.

Perdebatan yang muncul dalam rapat pembahasan merupakan dinamika yang lazim terjadi hampir disetiap tahun anggaran. Karena mekanisme interaksi antar DPRD dan Bupati dalam kondisi tertentu saling mendominasi ketimbang 
bersifat check and balance. Tindakan mendominasi antara kedua kekuasaan ini masing-masing diorientasikan untuk memobilisir kepentingan dan program agar dapat terakomodir saat proses penentuan dan alokasi anggaran.

Rumusan anggaran atau rancangan APBD yang telah diseain oleh Pemerintah Daerah tidak secara langsung dipandang ideal oleh DPRD. Karena DPRD juga memiliki kepentingan relasional dengan konstituen untuk memenifestasikan hasil identifikasi masalah yang dijaring melalui program reses. Dalam proses pembahasan APBD, DPRD berupaya agar aspirasi masyarakat yang dijaring melalui program reses tersebut dapat terakomodir dalam postur APBD. Sehingga hal ini menimbulkan perdebatan antara DPRD dan Pemerintah Daerah saat proses pembahasan anggaran. Argument perdebatan tidak keluar dari hal-hal yang bersifat prinsipil. Bahkan DPRD baik secara pribadi maupun kelembagaan selalu mengingatkan kepada Tim Anggaran Pemerintah Daerah (TAPD) agar tidak melakukan pemangkasan terhadap anggaran yang dianggap memberikan jaminan kesejahteraan terhadap masyarakat terutama anggaran pemberdayaan masyarakat.

Pemangkasan anggaran atau "rasionalisasi anggaran" di masa pemerintahan Bupati Beny Laos telah memberikan stimulus terhadap atmosfir interaksi yang bersifat konfliktual. Karena politik anggaran secara tidak langsung di dominasi oleh eksekutif-Bupati. Dominasi Bupati diperlihatkan melalui mekanisme normative, misalnya, perencanaan dan pengajuan anggaran sepenuhnya menjadi otoritas Bupati. Sedangkan DPRD memiliki peluang sangat minim dalam merencanakan pokok-pokok pikiran atau masalah yang diidentifikasi melalui program reses untuk bisa terakomodir dalam postur APBD. Karena DPRD tidak memiliki pengaruh determinan seperti Bupati khususnya otoritas perencanaan dan pengajuan anggaran. Disisi lain, DPRD juga tidak memiliki kapasitas yang memadai untuk mengkritisi anggaran secara rinci dan menyeluruh.

Meski demikian, DPRD mengandalkan fungsi anggaran untuk menerobos batas kemampuan argument pemerintah daerah untuk mempengaruhi postur APBD. Selain itu, ada factor yang lebih determinan dalam politik anggaran, yaitu 
tidak semua kepentingan DPRD dapat tercover secara keseluruhan dalam postur APBD, karena secara substansial APBD merupakan anggaran daerah yang memilik daya dan kapasitas mobilir kepentingan dan program terbatas pada satu tahun anggaran. Sehingga kepentingan dan program Bupati maupun DPRD diseting seproporsional dan serasional mungkin agar APBD terlihat lebih proporsional dan demokratis.

Namun, upaya mendesain anggaran lebih rasional oleh Pemda ternyata berpotensi memicu ketidak stabilan interaksi Bupati dan DPRD. Pembahasan anggaran tahun 2018, misalnya, Bupati melalui Tim Anggaran Pemerintah Daerah (TAPD) mengambil langka kebijakan efesiensi dengan cara melakukan rasionalisasi (pemangkasan) anggaran disetiap SKPD dan DPRD. Hal penting yang harus diketahui adalah kebijakan rasionalisasi anggaran, satu diantaranya dilakukan terhadap biaya perjalanan dinas baik pegawai/pejabat yang ada di SKPD maupun perjalanan dinas Anggota DPRD. Kebijakan tersebut diorientasikan untuk mengefektifkan atau didistribusikan secara proporsional pada program pemberdayaan masyarakat khususnya pemberian tunjangan kepada lansia, imam, pendeta, janda, yatim-piatu, cacat/disabilitas, dll.

Kebijakan efesiensi anggaran tidak langsung diputuskan secara consensus oleh "sebagian Anggota DPRD”, walaupun pada akhirnya kedua lembaga tersebut mendaptkan kata sepakat. Akan tetapi, praktik-praktik informal seperti mendeligitimasi anggaran membuat dinamika terus berlanjut diluar lingkup pembahasan anggaran. Faktanya, "sebagian anggota DPRD” mengembangkan argument bahwa Pemkab Pulau Morotai terindikasi melakukan perubahan atas Dokumen APBD Tahun 2018. Artinya bahwa anggaran tahun 2018 dipandang tidak memiliki keabsahan secara konstitusional. Sehingga tidak layak diterapkan untuk membiayai segala program dan kebijakan pemerintah daerah.

Atmotsfir kemitraan yang bersifat konfliktual telah memberikan celah bagi oknum Anggota DPRD untuk terus berupaya melakukan praktik-praktik informal. Ketua DPRD berargumen bahwa ada indikasi Pemkab Morotai merubah dokumen APBD 2018 (Indotimur.com, 25 Januari 2018). Menurut Wakil Ketua II, Rasmin Fabanyo, APBD yang disampaikan ke Pemprov untuk di evaluasi merupakan 
APBD yang tidak melalui persetujuan bersama (I-malut.com, 6 Februari 2018). Atmosfir konfliktual ini tercipta, menurut Bupati karena sebagian Anggota DPRD tidak menerima adanya pemangkasan atau rasionalisasi anggaran DPRD (Inspiratormedia.id, 20 Desember 2018). Namun hingga berakhirnya APBD 2018, argument APBD manipulatif atau fiktif yang didengungkan oleh beberapa “Anggota DPRD” seakan mendapat legitimasi dan dianggap sah secara formil.

Meskipun pada sesi berbeda Ketua DPRD membangun opini tentang indikasi fiktifnya dokumen APBD 2018, tapi disesi argument yang lain, Ketua DPRD juga mengakui bahwa APBD 2018 memiliki kebasahan yuridis karena sudah dibahas dan disetujui oleh kedua lembaga, DPRD dan Bupati. Bahkan angka-angka yang terdapat dalam postur dokumen APBD pun tidak berubah (Wawancara, 3 September 2019).

Sekarang kita bisa mendiskripsikan pola interaksi DPRD dan Bupati dalam mekanisme pembahasan anggaran dengan mengembangkan argument bahwa, interaksi kedua kekuasaan ini berjalan dibarengi dengan perdebatan kepentingan dan akhirnya terlihat tidak demokratis melainkan berada pada relasi yang bersifat konfliktual. Relasi konfliktual ini dikonstruksikan melalui perdebatan kepentingan konstituen selain praktik-praktik informal seperti: "sebagian anggota DPRD" membuat konklusi mengenai ketidakabsahan anggaran yang secara formal sudah disepakati bersama oleh kedua lembaga tersebut.

\section{Dinamika Interaksi dalam Agenda Legislasi}

Undang-Undang Pemerintahan Daerah menyebutkan bahwa hubungan kerja antara DPRD dan kepala daerah didasarkan atas kemitraan yang sejajar. Relasi kemitraan dimanifestasikan dalam berbagai macam bentuk kerja relasional, salah satu diantaranya adalah persetujuan bersama dalam pembentukan Peraturan Daerah.

Berdasarkan Pasal 26 ayat (2) UU No. 23 Tahun 2014 tentang Pemerintahan Daerah, Perda dibentuk oleh DPRD dengan persetujuan bersama Kepala daerah. Kekuasaan membentuk Perda tidak lagi melekat kepada Kepala daerah melainkan DPRD. Sedangkan Kepala daerah diberikan kekuasaan 
mengajukan rancangan Perda. Hal ini sejalan dengan logika UUD 1945, yang melegitimasikan DPR sebagai pemegang kekuasaan membentuk undang-undang dan Presiden mempunyai kekuasaan mengajukan rancangan undang-undang. Pembentukan Perda pada prinsipnya dimulai dengan sebuah perencanaan yang dapat berasal dari Pemerintah Daerah maupun DPRD, yang dikemas dalam bentuk program legislasi daerah (Prolegda). Secara yuridis, Prolegda diterminologikan sebagai suatu instrument perencanaan program pembentukan peraturan daerah yang disusun secara terencana, terpadu dan sistematis (Alwadud, 2018:111).

Perihal penting untuk mengevaluasi interaksi DPRD-Bupati adalah kerja relasional khususnya agenda legislasi. Sebagaimana tercantum dalam undangundang pemerintahan daerah yang mengatur relasi antara DPRD dan Bupati, program pembentukan peraturan daerah disetujui dan dilaksanakan setiap tahun. Dalam program pembentukan peraturan daerah, rancangan Perda dapat berasal dari inisiatif Bupati dan DPRD.

Selama periode 2017-2019, kerja relasional DPRD dan Bupati khususnya pembentukan peraturan daerah telah berhasil menerbitkan 20 peraturan daerah dari 39 rancangan Perda yang terencana dalam program pembentukan perda (prolegda/insidentil), yang pertahunnya berfariatif, yaitu 2017 berjumlah 6 Perda, 2018 berjumlah 13 Perda dan 1 Perda ditahun 2019 (hingga pelaksanaan penelitian selesai).

Selama periode 2017-2019, dari 20 rancangan Perda yang berhasil di disahkan menjadi Perda, 18 diantaranya merupakan hasil inisiasi Bupati. Selama tiga tahun itu, DPRD dengan kamampuan legislasinya menghasilkan 2 inisiatif pembentukan Perda. Sedangkan dari 39 rancangan Perda yang telah ditargetkan dalam program pembentukan Perda (prolegda/insidentil), inisiatif Bupati jauh lebih dominan, yaitu 37 rancangan Perda dan 2 rancangan Perda oleh DPRD. Dari hasil identifikasi menunjukan bahwa interaksi antara DPRD dan Bupati khususnya pembentukan Perda jauh lebih produktif Bupati ketimbang DPRD.

Namun, dominasi inisiatif rancangan Perda bukanlah determinasi kekuasaan Bupati atas kewenangan DPRD. Melainkan produktifitas legisalasi 
Bupati merupakan respon atas kebijakan dan pembangunan daerah yang membutuhkan landasan hukum yang kuat. Karena Bupati adalah kepala daerah yang memiliki tugas sebagai pelaksana kebijakan atau peraturan perundangundangan. Selain itu, produktifitas legislasi Bupati juga didukung oleh perangkat sumber daya manusia yang mumpuni (satuan kerja perangkat daerah). Sehingga kemajuan dan produktifitas legislasi Bupati harus dibaca sebagai kelaziman atau keniscayaan dalam membangun dan melaksanakan kebijakan daerah.

Menurut Jimly Asshiddiqie, DPRD Kabupaten/Kota yang terdiri atas para politisi lokal yang hanya dipersyaratkan minimum lulusan SLTA, dan hanya bekerja untuk masa kerja lima tahunan, tentu tidak dapat diandalkan untuk mempersiapkan bahan rancangan dan data-data pendukung dalam proses pembentukan peraturan daerah itu melebihi kemampuan yang dapat dilakukan oleh aparat pemerintah. Oleh karena itu, peran yang perlu diperkuat dari DPRD adalah fungsinya sebagai pengontrol atau pengendali proses pembentukan peraturan daerah daripada mengutamakan peran sebagai inisiator (Jimmly, 2006:298).

Ada variable alternatif lain yang mempengaruhi kenapa produktifitas legislasi DPRD berada dibawah dominasi Bupati. Salah satu diantaranya, interaksi antara DPRD dan Bupati tercipta tidak secara formal-prosedural khususnya pada tahap awal pembentukan Perda (prolegda). Selama ini (periode 2017-2019) proses pembentukan Perda tidak sesuai dengan prosedur peraturan perundang-undangan yang berlaku. Dalam artian bahwa kedua lembaga tersebut tidak memiliki instrument perencanaan program pembentukan Perda yang disusun secara terencana, terpadu dan sistimatis. Sehingga DPRD hanya mengandalkan kemampuan legislasi Bupati yang bersifat insidentil untuk memenuhi ketercapaian fungsi legislasi. Prospek pembangunan produk hukum daerah seakan tidak memiliki nilai urgensitas untuk menciptakan instrument kebijakan dan pembangunan daerah.

Tradisi program pembentukan Perda selama ini yang dipakai kedua lembaga, DPRD dan Bupati hanya berdasar pada kebutuhan yang bersifat insidentil. Apabila dalam proses penyelenggaraan pemerintahan Bupati 
melaksanakan kebijakan tertentu yang membutuhkan unstrumen hukum daerah (Perda), maka Sekretaris daerah melalui perangkat daerah yang membidangi bagian hukum mengirimkan surat pengantar penyampaian rancangan Perda kepada DPRD dan selanjutnya dijadwalkan untuk dibahas secara bersama. Akhirnya, dengan praktik tersebut, instrument hukum daerah tidak terencana, terpadu dan sistimatis.

Meski demikian, interaksi antara DPRD dan Bupati di Pulau Morotai khusunya pada proses pembahasan rancangan Perda relatif jauh lebih dinamis, daripada pembahasan rancangan Perda APBD yang menyumbangkan begitu tinggi kedinamisan interaksi. Namun, tidak bisa dipungkiri ada beberapa hal memang terjadi konflik tetapi sejauh ini kita tidak menemukan adanya kebuntuan kerja relasional. Selama periode 2017-2019, rancangan Perda yang dibahas oleh kedua lembaga tersebut tidak pernah menemui kebuntuan. Rancangan Perda Pembiayaan Kontrak Tahun Jamak Kabupaten Pulau Morotai 2019-2021 merupakan satu diantara rancangan Perda yang sempat mengalami perdebatan panas walaupun pada akhirnya berhasil diundangkan.

Perdebatan tidak hanya melibatkan anggota DPRD sebagai personal, namun hal menarik yang menambah potensi dinamika kerja relasional kedua lembaga tersebut adalah mengenai pokok pikiran alat kelengkapan DPRD khususnya Fraksi. Dalam pembahasan mengenai rancangan Perda Pembangunan Kontrak Tahun Jamak/Multi Years Contract tahun 2019-2021 empat fraksi (Fraksi Golkar, Fraksi PDIP, Fraksi Pembangunan Amanat Demokrasi dan fraksi Kebangkitan Nurani Nasional) menyetujui format penganggaran melalui pembiayaan Kontrak Tahun Jamak (multy years contract) untuk beberapa program dan Fraksi PKS abstain dari rapat pembahasan.

Kerja relasional antara DPRD dan Bupati Pulau Morotai selalu mengkonfirmasi perdebatan walaupun pada akhirnya bermuara pada konsensus. Hal tersebut menunjukan bahwa desain kelembagaan eksekutif dan legislatif daerah memiliki mekanisme yang interdependensi. Sehingga kebuntuan dalam proses kerja relasional antara kedua lembaga tersebut, baik dalam perumusan anggaran maupun proses legislasi dapat terhindarkan. Meski demikian, tidak bisa 
dipungkiri beberapa konflik telah menambah dinamika interaksi antara DPRD dan Bupati. Dinamika tersebut juga telah membentuk pola interaksi konfliktual atau tidak demokratis.

Jika interaksi legislatif dan eksukutif daerah berada pada pola yang tidak demokratis, maka pada aras program dan penentuan politik anggaran akan memicu potensi saling sandra antara pemerintah daerah dengan DPRD. Geliat demikian menstimuluskan penyelenggaraan pemerintahan daerah dengan memakai jalan yang tidak demokratis, sehingga dapat mengancam stabilitas demokrasi lokal. Resiko lain dari instabilitas demokrasi lokal adalah memungkinkan adanya ekspansi kekuatan Pemerintah Daerah secara kelembagaan ke tubuh DPRD untuk membentuk faksi politik mayoritas dengan orientasi mengamankan berbagai opsi kepentingan, baik yang berkorelasi dengan masalah kinerja pemerintahan daerah maupun ekonomi-politik di daerah.

Dalam membaca interaksi politik dan hukum itu, dalam rumpun Peraturan Daerah ini ada kesamaan dengan rumpun-rumpun sebelumnya. Kesamaan itu nampak dalam Pada saat rapat kerja dengan Perangkat Daerah inilah interaksi sistem politik yang sebenarnya terjadi. Dalam interaksi tersebut akan terjadi proses tawar-menawar dan adu argumentasi dalam rangka memperoleh kesamaan persepsi antara Panitia Khusus dengan Perangkat Daerah terhadap substansi Rancangan Peraturan Daerah. Dengan tawar menawar, saling adu argumentasi, dan saling pengaruh-mempengaruhi tersebut akan dapat dicapai kesepakatankesepakatan terkait apakah Rancangan Peraturan Daerah layak dilanjutkan, tidak dilanjutkan, atau ditunda pembahasannya (Isharyanto \& Adriana, 2013:40).

\section{Konfigurasi Politik dan Penjelasan Alternatif}

Secara etimologi, konfigurasi (configuration) diartikan sebagai bentuk atau susunan. Dalam tafsir semantic, menurut Suparman Marjuki, "konfigurasi politik" adalah susunan atau tata letak atau konstalasi kehidupan politik yang terdapat pada suatu masa, yang menggambarkan suatu keadaan politik pada masa tersebut (Suparman Marzuki, 2011:149). Sementara Mahfud MD mengartikan konfigurasi politik sebagai susunan atau konstalasi kekuatan politik (Mahfud, 2014:30). 
Konfigurasi politik diarena electoral tahun 2017 terlihat dinamis dan kompetitif karena masing-masing partai pengusung memainkaan peran dan strategi untuk memenangkaan pasangan calon. Pasangan Benny Laos-Asrun Padoma diusung oleh mayoritas partai politik, yaitu PDI Perjuangan, Golkar, Gerindra, Demokrat, PKB, dan Nasdem dengan presentasi perolehan suara 49.74\%. Sedangkan pasangan Ali Sangaji-Yulce Makasarat diusung oleh PKS, PPP dan PAN dengan presentase perolehan suara 34.49\%. Dalam arena yang sama, rivalitas politik tidak hanya melibatkan elit partai politik, karena disisi lain, ada pasangan Ramli Yaman-Adjan Djaguna yang tampil melalui jalur independen dengan presentase perolehan suara $15.77 \%$.

Tahap awal pemilihan kepala daerah tahun 2017 merupakan permulaan sensasi pembentukan konfigurasi politik diarena electoral. Hal menarik yang perlu dikuliti dalam lingkup konfigurasi adalah mengenai kekuatan partai pengusung minoritas dan mayoritas. Partai politik pengusung minoritas secara politik ternyata memiliki kekuatan determinasi dalam menyedot suara dibasis masyarakat. Hal ini menunjukan bahwa relasi partai yang berhasil dalam arena pemilu legislatif 2014 kekuatan politiknya relatif dialektis dan tidak konstan. Sehingga basis masyarakat yang termobilisasi dalam arena pemilu, lebih dari seratus persen, basis tersebut memberikan sumbangsi pengaruh terhadap keberhasilan diarena Pilkada.

Fakta menunjukan, partai pengusung minoritas (PKS, PPP dan PAN) yang mengusung Ali Sangaji-Yulce Makasarat mendapatkan suara 7.409 (akumulasi suara partai pengusung) pada Pemilu 2014, mampu memobilisasi kekuatan suara diarena electoral tahun 2017 dengan perolehan suara 13.221. Hal tersebut berbeda dengan presentasi kemenangan partai pengusung mayoritas (PDI Perjuangan, Golkar, Gerindra, Demokrat, PKB, dan Nasdem) yang mengusung Benny LaosAsrun Padoma. Kemenangan diarena pemilu 2014 tidak secara signifikan memberikan dampak intensitas mobilisasi suara pada arena electoral. Jika diakumulasi perolehan suara diarena Pemilu, partai pengusung mayoritas tersebut, mendapatkan 22.743 suara, sedangkan pada arena electoral tahun 2017 berhasil memobilisasi 19.069 suara. 
Meskipun partai pengusung mayoritas berhasil memenangkan pesta electoral tahun 2017, namun koalisi dalam arena persaingan electoral tidak bersifat parmanen. Karena perilaku partai politik selalu berbeda diarena persaingan politik yang lain. Partai politik mungkin berprilaku berbeda diarena politik yang berbeda bukan merupakan hal baru. Robert Dhal dengan penelusuran diberbagai negara menungkapkan bahwa jenis interaksi partai politik berbeda diarena legislative tapi kompetitif diarena elektoral. Begitu juga sebaliknya, kompetitif diarena electoral namun sampai tingkat tertentu bersifat kooperatif diarena legislative (Ambardi, 2009:13). Dalam catatan konfigurasi, fakta politik telah memberikan sebuah justifikasi jika perilaku partai politik/anggota DPRD diarena electoral (pilkada) berbeda dengan arena pemerintahan/kebijakan. Argument tersebut dikonstruksikan berdasarkan kasuistik kebijakan yang melibatkan DPRD dan Bupati dalam pusaran perdebatan dan konflik kepentingan, meskipun pada akhirnya debat kepentingan disudahi dengan jalan politik consensus.

Pasca perhelatan demokrasi electoral tahun 2017, polemik kebijakan telah memberikan stimulus terhadap tumbuhnya sikap oposisi ditubuh legislative. Menariknya, pembentukan oposisi diarena persaingan legislative tidak berbasis partai politik melainkan berbasis kolegial, sehingga kekuatan oposisi diarena legislative tidak memiliki daya mobilisir yang kuat untuk mendebatkan kebijakan Bupati yang dianggap bertentangan dengan kepentingan umum.

Tercatat ada sekian isu dalam wacana interaksi legislatif-eksekutif Pulau Morotai telah memberikan konstribusi terhadap dinamika konfigurasi politik. Namun konfigurasi politik mengenai isu reformasi birokrasi hususnya mendisiplinkan honorer dan rasionalisasi (pemangkasan) anggaran DPRD merupakan dua isu yang menambah daya konfliktual dalam kerja relasional Bupati dan DPRD. Kebijakan mendisiplinkan honorer tidak dengan alasan melainkan Pemerintah Daerah dengan segudang argumen berdalil bahwa pemberhentian honorer yang tidak disiplin merupakan rasionalitas kebijakan untuk mengstabilkan APBD disatu sisi dan menciptakan serta meningkatkan etos kerja disiplin dilain sisi. 
Meski demikian, DPRD dengan wibawa politiknya berupaya melakukan resisten terhadap kebijakan tersebut melalui basis argumen bahwa jauh sebelumnya isu honorer tidak menjadi polemik utama dalam wacana pemerintahan daerah terutama berkaitan dengan instabilitas APBD. Namun untuk mengakhiri polemic tersebut, DPRD dan Bupati mencari jalan kompromi dengan menyeleksi ulang tenaga honorer melalui seleksi Tenaga Kontrak Daerah (TKD), yang masa kontraknya terbatas (1 tahun).

Hal penting yang harus diketahui juga adalah kebijakan rasionalisasi anggaran, satu diantaranya dilakukan terhadap biaya perjalanan dinas baik pegawai/pejabat yang ada di SKPD maupun perjalanan dinas Anggota DPRD. Kebijakan efesiensi anggaran tidak langsung diputuskan secara consensus oleh "sebagian Anggota DPRD”, walaupun pada akhirnya kedua lembaga tersebut mengakhiri debat dengan jalan kompromis. Akan tetapi, praktik-praktik informal seperti mendeligitimasi anggaran membuat dinamika terus berlanjut diluar lingkup pembahasan anggaran. Faktanya, "sebagian anggota DPRD" mengembangkan argument bahwa Pemkab Pulau Morotai terindikasi melakukan perubahan atas Dokumen APBD Tahun 2018 yang telah disepakati bersama. Artinya bahwa anggaran tahun 2018 dipandang tidak memiliki keabsahan secara konstitusional. Sehingga tidak layak diterapkan untuk membiayai segala program dan kebijakan pemerintah daerah.

Kita berhasil mengidentifikasi kerja relasional DPRD dan Bupati khusunya lingkup politik anggaran maupun agenda legislasi serta mengurai konfigurasi politik yang berkembang dalam kerja relasional, yang mengkonstruksikan pola relasi yang bersifat konfliktual namun berakhir dengan politik consensus. Mekanisme interaksi kedua lembaga tersebut secara normatif memang di desain untuk tidak saling menjegal sehingga seberapa besar konflik yang tercipta dalam proses kerja relasional tidak berakhir deadlock. Namun ada penjelasan alternative yang mendeskripsikan kenapa kerja relasional-konfiliktual DPRD dan Bupati selalu berakhir dengan consensus dan tidak berakhir deadlock?.

Manuver politik adalah kunci utama dalam menyelesaikan debat kepentingan. Karena interaksi antar DPRD dan Bupati dalam lingkup maneuver 
politik memperlihatkan dinamika yang menarik. Dinamika ini tentunya bersumber dari inkonsistensi sikap “anggota DPRD” yang dalam kelembaga memiliki posisi kunci dan berpengaruh. Inkonsistensi tersebut, jika kita kembali pada kontruksi analisis awal, kita temukan ada upaya pemerintah daerah mencari jalan alternative untuk menstabilkan interaksi dengan DPRD melalui sikap kompromistis. Hal ini teridentifikasi dari sikap Ketua DPRD yang semula mengeluarkan pernyataan bahwa APBD 2018 fiktif, kemudian dikesempatan yang lain, dengan pernyataan yang berbeda menyatakan bahwa APBD itu sudah dibahas dan memiliki daya ikat konstitusional.

Inkonsistensi sikap dalam debat kepentingan, jika ditelisik menggunakan teisis kartel maka kita bisa membangun dalil bahwa kerja relasional eksekutiflegislatif daerah yang bersifat konfliktual dan berakhir dengan konsensus atau kompromistis serta terlampau stabil dalam arena kebijakan eksekutif, karena legislatif dan eksekutif daerah melakukan kongkalikong untuk mendapatkan sumber finansial politik dalam berbagai bentuk, seperti proyek pemerintahan, atau politik patronase lainnya. Menurut logika kartel, debat kepentingan atau persaingan antara eksekutif dan legislatif daerah tidak diperlukan lagi dalam kerja relasional karena anggota legislative tidak terlalu peduli dengan kebijakan pemerintah daerah selama mereka mendapatkan sumber finansial politik.

Meskipun penjelasan kartelisasi tidak memuaskan sebagai analisi umum, namun saya sedikit mengamini karena dari rangkaian konfliktual dalam kerja relasional DPRD dan Bupati selalu saja berakhir dengan politik consensus. Tidak hanya itu, pasca politik consensus hingga saat ini relasi kedua lembaga tersebut terlihat lebih stabil dan oposisi baik berbasis partai maupun kolegial lenyap dari arena persaingan di legislatif. Menurut Slater (dalam Djayadi, 2014:76), tanpa adanya oposisi di legislative tidak mungkin ada akuntabilitas yang sejajar antara legislative dan eksekutif. Jika dinamika itu yang terjadi, maka dalam istilah Slater disebut "Jebakan Akuntabilitas". 


\section{KESIMPULAN}

Dalam catatan konfigurasi, interaksi antara kedua lembaga tersebut terlihat tidak demokratis melainkan berada pada relasi yang bersifat konfliktual meskipun pada akhirnya interaksi kuasa dalam arena tertentu berakhir dengan konsensus. Hal tersebut menunjukan bahwa desain kelembagaan eksekutif dan legislatif daerah memiliki mekanisme yang interdependensi. Sehingga kebuntuan dalam proses kerja relasional antara kedua lembaga tersebut, baik dalam perumusan anggaran maupun proses legislasi dapat terhindarkan. Penjelasan alternative menunjukan bahwa dari rangkaian konfliktual dalam kerja relasional DPRD dan Bupati selalu saja berakhir dengan politik consensus. Pasca politik consensus hingga saat ini relasi kedua lembaga tersebut terlihat lebih stabil dan oposisi secara politik lenyap dari arena persaingan di legislatif.

\section{DAFTAR PUSTAKA}

Ambardi, Kuskridho, Mengungkap Politik Kartel: Studi tentang Sistem Kepartaian di Indonesia Era Reformasi. Cetakan Pertama. Jakarta: KPG, 2009.

Asshiddiqie, Jimly, Perkembangan dan Konsulidasi Lembaga Negara Pasca Reformasi. Cetakan Pertama. Jakarta: Sekretariat Jendral dan Kepaniteraan MK RI, 2006.

Hanan, Djayadi, Menakar Presidensialisme Multi Partai Di Indonesia. Cetakan Pertama. Bandung: Al-Mizan, 2014.

Isharyanto \& Adriana Grahani Firdausy, "Interaksi Politik dan Hukum dalam Pembentukan Legislasi Daerah”, Jurnal Yustisia, Vol.2, No.3, 2013.

Lule, Alwadud, Problematikan dan Idealitas Pengawasan Produk Hukum Daerah. Cetakan Pertama. Jakarta: Rajawali Pers, 2018.

Marzuki, Suparman, Tragedi Politik Hukum HAM. Cetakan Pertama. Yogyakarta: Yogyakarta, 2011.

MD, Mahfud, Politik Hukum Di Indonesia. Edisi Revisi. Cetakan Keenam. Jakarta: PT RajaGrafindo, 2014. 


\section{Koran dan Internet}

Indotimur.com. (25 Januari 2018). Pemkab Pulau Morotai Diduga Rubah APBD 2018 Tanpa Persetujuan DPRD.

I-malut.com. (6 Februari 2018). Presidium Koalisi Masyarakat Bersatu Desak DPRD Morotai Gunakan Hak Interpelasi.

Inspiratormedia.Id. (20 Desember 2018). Dugaan APBD Bodong Di Morotai, Bupati Beny Laos Salahkan DPRD. 